\title{
ENTERPRISE BREAKUPS AND PERFORMANCE DURING THE TRANSITION FROM PLAN TO MARKET
}

\author{
Lubomir Lizal, Miroslav Singer, and Jan Svejnar*
}

\begin{abstract}
Using firm-level data, we estimate the effects of the major wave of 1991 breakups of Czechoslovak state-owned enterprises on the subsequent performance of the "master enterprises" and spun-off divisions. We estimate the performance effects of spinoffs by comparing the performance of enterprises that remained intact throughout the 1990-1992 period to the performance of the master enterprises that experienced spinoffs and the newly spun-off subsidiaries. Our estimates suggest that the breakups had a significant immediate effect on the productive efficiency and on the profitability of industrial firms in 1991, and that the effect became much less significant in 1992. The effect is a negative function of the size of the spinoff, being positive for small to slightly above average-sized spinoffs and negative for very large ones. We cannot reject the hypothesis that the estimated effect was identical for the spun-off subsidiaries and the master enterprises that experienced the spinoffs. Our 1991 estimates suggest that the large firms created under the centrally planned system suffered from inefficiencies that were alleviated by the breakups. The 1992 estimates are consistent with increased competition and the appropriation of profits by managers.
\end{abstract}

\section{Introduction}

A $S$ the central and eastern European (CEE) countries embarked on the transition from a planned to a market economy in the early 1990s, the restructuring of stateowned enterprises (SOEs) became a major policy issue. From the standpoint of altering the size and number of firms and bringing in new management, one of the most important forms of restructuring observed during the CEE transition was the massive breakup of SOEs in Czechoslovakia and, to a lesser extent, in Hungary in the early 1990s. In Czechoslovakia, many divisions (subsidiaries) of SOEs applied to their supervisory ministries for permission to break away from their "master enterprise" in the 1990-1991 period. The ensuing process of negotiations among government officials, top managers of the SOEs, and divisional managers resulted in a phenomenal wave of spinoffs, giving rise to a large number of new firms led by new top management. In particular, although Czechoslovakia started in 1990 with approximately 700 industrial enterprises (those employing more than 25 workers), by mid-1992 the number of industrial firms in this category had virtually tripled to approxi-

Received for publication October 30, 1997. Revision accepted for publication February 9, 2000.

* CERGE-EI, Prague, and The William Davidson Institute at the University of Michigan Business School; CERGE-EI and Expandia Finance, Prague; and The William Davidson Institute at the University of Michigan Business School, Department of Economics at the University of Michigan and CERGE-EI, Prague, respectively.

The research in this paper was supported by ACE grant 94-0618-R, NSF grant SBR-951-2001 and an institutional support grant of the Czech Grant Agency to CERGE and EI, 402/95/0789. The paper benefitted from presentations at CERGE-EI, the Free University of Brussels, the 1996 American Economic Association Meeting, the 1996 European Economic Association Meeting, and presentation at the University of Michigan. We would like to thank Daniel Berkowitz, Olivier Blanchard, John Bonin, John Ham, Jan Kmenta, Francine Lafontaine, Lester Taylor, Katherine Terrell, three anonymous referees, an editor for valuable comments on earlier drafts of the paper and Czech Statistical Office for the data. mately $2000 .{ }^{1}$ This restructuring preceded other major reforms, as prices were still under state control in 1990; even in 1991, when prices were by and large free, the state still owned the firms. ${ }^{2}$

The important question that arises is whether the breakups had systematic economic effects by improving or worsening the performance of the spun-off subsidiaries and/or the remaining master enterprises. We address this issue by analyzing 1990-1992 enterprise-level data that relate to the breakups of Czechoslovak SOEs during the 1990-1991 period. ${ }^{3}$ Because the Czech and Slovak republics are among the leading transition economies whose policies have been followed by other countries (World Bank, 1996) —and because the two republics have displayed major problems with management's appropriation of profit in the presence of weak ownership and legal frameworks (Lizal, Singer, \& Svejnar, 1995; Ellerman, 1998; Weiss \& Nikitin, 1998; Stiglitz, 1999) - our findings are of general interest in the transition context.

\section{A Conceptual Framework for Spinoffs and Breakups}

The literature on the desirability of takeovers, mergers, and breakups of firms in market economies focuses on the tradeoff between transaction costs via markets and the internal inefficiencies within organizations. ${ }^{4}$ In the context of the transition, the conceptually more relevant studies focus on the bargaining between the key decision-makers who, depending on the context, are managers, government officials (politicians), workers, and new private owners. ${ }^{5}$

\footnotetext{
${ }^{1}$ The latter number includes newly created firms. However, because only firms with more than 25 employees are included, most of the growth in the number of firms has been brought about by the breakups of SOEs. It should also be noted that the breakup of firms in the transition economies has other aspects than those that we study in this paper. For instance, the process includes the unbundling of social-service activities (such as clinics and kindergartens) and service activities for the workforce (such as food and beverage manufacture and holiday homes). These spinoffs generate small firms (often with fewer than 25 workers) that operate in industries other than the core activity of the firm. Although important, they are not the subject of our analysis.

2 Yet, as discussed by Kotrba (1995) and Zemplinerova and Stibal (1995), the outcome of the process of enterprise breakups had important implications for the structure of industry and the subsequent program of privatization.

${ }^{3}$ We build on previous work (Lizal et al., 1995) by using a better data set and superior analytical techniques to address the issue.

${ }^{4}$ See, for example, Coase (1937), Alchian and Demsetz (1972), Williamson (1975, 1985), Chandler (1990), Klein, Crawford, and Alchian (1978), Grossman and Hart (1986), Lichtenberg and Siegel (1987), Ravenscraft and Scherer (1987), Hart and Moore (1990), Kaplan and Weisbach (1992), and Radner and van Zandt (1992).

${ }^{5}$ See, for example, Aghion, Blanchard, and Burgess (1994), Shleifer and Vishny (1994), Prasnikar et al. (1994), and Lizal et al. (1995).
} 
In the case of Czechoslovakia, the principal factors leading to the 1990-1991 breakups of SOEs appear to have been the goals of the opportunities open to the top management of the SOEs and the management of the divisions of these SOEs. In particular, managers of many divisions of SOEs applied to the supervisory ministries for permission to spin off from their master enterprises. The government displayed a relatively passive posture toward the restructuring and breakups of SOEs, because the ministries were charged with screening rather than initiating the spinoffs. Moreover, because the majority of applications for spinoffs were submitted and processed in the last quarter of 1990 and the first quarter of 1991, the ministries worked under time constraints and had little time to encourage applications. ${ }^{6}$ The institutional information hence suggests that breakups and spinoffs were initiated by the management of either the master enterprise or the subsidiary.

In conceptualizing the process, note that the compensation of the top management of the firm before the breakup is an increasing function of performance of the entire firm, although after the split it is a positive function of the performance of only the remaining master enterprise. Analogously, the compensation of the management of a subsidiary before the breakup is an increasing function of performance of the entire firm, adjusted for the relative importance of the subsidiary, but it becomes a positive function of the performance of the subsidiary after the split. Rational behavior of managers in this setting yields two competing hypotheses:

1. Breakups occur because the top managers of the SOEs discard poorly performing divisions to improve the performance of the (remaining) master enterprises.

2. Breakups are observed because managers of the divisions (subsidiaries) of SOEs spin more-efficient units away from the master enterprises.

Because firms created under communism tended to be artificially large, we also examine a third hypothesis that the SOEs suffered from inefficiencies such as diseconomies of scale and that the performance of the constituent units could be improved by unbundling:

3. Breakups occur because the large SOEs suffer from inefficiencies such as diseconomies of scale, and breakups result in a superior performance of both the spun-off units and the remaining master enterprises.

Finally, we allow for a fourth hypothesis that, as government supervision of management waned and control over management remained weak in the absence of a solid legal

\footnotetext{
${ }^{6}$ During this time period, the ministry employees were themselves being screened as to whether they had belonged to the communist "nomenclatura" or had worked for the former security police. They were thus under extreme pressure not to transgress their narrowly defined duties.
}

framework, appropriation of profit and asset stripping by managers ("tunneling") has become a serious problem:

4. Breakups occur because managers of subsidiaries benefit from being the top management of a firm even if their unit and the master enterprise perform worse as a result of the breakup.

In this fourth scenario the utility of managers of divisions does not depend on the performance of their firms, and the pursuit of managerial goals worsens enterprise performance.

The four hypotheses hence provide a rationale for observing the following four outcomes:

1. The effect of a breakup on performance is positive for the master enterprise and negative for the subsidiary (hypothesis 1).

2. The effect is positive for the subsidiary and negative for the master firm (hypothesis 2).

3. The effect is positive for both the master enterprise and the subsidiary (hypothesis 3 ).

4. The effect is negative for both units (hypothesis 4).

The magnitude of the effects implied by hypothesis 1 through 4 of course depend upon the overall economic environment. An important countervailing effect is brought about by increased competition stemming from the breakups of large firms with monopolistic power and from the opening up of the formerly planned economies to world trade. In particular, increased competition exerts downward pressure on output prices and thus reduces nominal value added and profits. Moreover, the Czechoslovak authorities eliminated quantitative import restrictions as early as 1990, and the average level of trade-weighted tariffs became as low as 5\% (Drabek \& Smith, 1995). However, in 19901991, the firms in Czechoslovakia were temporarily protected by a uniform 20\% import surcharge tax (Dyba \& Svejnar, 1995). Trade with Western economies experienced a phenomenal boom and, by mid-1990, exceeded the value of trade with the former Soviet bloc countries (Dyba \& Svejnar, 1995). Thus, one may expect that the combined effect of the breakups of monopoly firms and the 1992 elimination of the $20 \%$ import surcharge would reduce any positive impact of breakups on value added and profits in 1992 as compared to the immediate effect observed in 1991. We take these effects into account as we interpret our econometric estimates.

\section{The Empirical Analysis}

\section{A. The Data and Identification of Breakups}

Our empirical analysis is based on quarterly and annual data reported by firms to Czechoslovakia's Federal Statistical Office and Ministry of Finance during the 1990-1992 
period. The data cover all industrial enterprises that employ more than 25 employees.

Although carefully assembled, the data set contains no explicit indicator of the breakups because no unplanned changes of industrial structure were expected under central planning. In order to identify the breakups, we exploited a special feature of statistical reporting. The system required enterprises to report the preceding year's values of variables together with the current values. Moreover, enterprises experiencing spinoffs were required to report preceding-year values corresponding to the remaining (postbreakup) part of the enterprise. If a breakup occurred, the remaining master enterprise therefore reported both the current and preceding year's data corresponding to its new (smaller) size. Using quarter-by-quarter comparisons, we identified the breakups and the quarter of their occurrence. ${ }^{7}$

Using the quarterly and monthly data, we are able to identify 476 enterprises that were present in the data set from the first quarter of 1990 to the fourth quarter of 1992. We dropped approximately 80 of these 476 firms because they provided inadequate information; and some observations were also lost as we collected data for the same set of firms for 1992. Overall, in most regressions, we are able to use data for 373 firms for 1991 and 262 firms for 1992.

Using the above-mentioned procedure for identifying spinoffs, eliminating firms that did not adequately fill out questionnaires and ignoring potential spinoffs involving less than $5 \%$ of the labor force or fewer than five employees, we were able to identify 152 firms that experienced spinoffs. Most (78) of these spinoffs occurred in the first quarter of 1991, 57 occurred in the last quarter of 1990, and few occurred in the second quarter of 1990 and in the remaining quarters of 1991. We use data from firms that experienced spinoffs in the first quarter of 1991. By doing so, we resolve the problem of endogeneity of regressors because we use 1990 values as exogenous variables for the 1991 and 1992 regressions. Of the 78 spinoffs that occurred in the first quarter of 1991, 66 yielded data that could be used in our analysis in 1991, and at least fifty generated data that could be used for 1992 .

Although the above data exercise allows us to compare the performance of master enterprises that experienced spinoffs to the performance of those that did not, it does not permit us to link the spun-off units to their former master enterprises or to estimate the effect on the spun-off units. To be able to do so, we carried out puzzle-like comparisons of the values of variables, such as the number of employees in the newly established companies with the decrease in the value of these variables in the master enterprises that were identified as experiencing spinoffs. To generate a meaningful number of observations, we were also forced to impose the assumption that the spun-off units operate in the same or similar industry as their master enterprises. This enabled us

\footnotetext{
${ }^{7}$ An example showing the identification of breakups may be found in Lizal et al. (1995).
}

to identify 28 pairs of masters and spun-off subsidiaries, 27 of which were usable in our work. ${ }^{8}$

\section{B. The Econometric Models}

The comparisons of means indicate that, in 1990, there were no significant differences in performance between firms that later experienced spinoffs and those that did not, ${ }^{9}$ and so our empirical strategy is to estimate the performance effect of a spinoff by comparing the performance of enterprises that were present throughout the 1990-1992 period but did not experience any spinoffs to the performance of the master enterprises that did experience spinoffs and also to the newly spun-off subsidiaries. The method amounts to comparing the performance of a treatment group (those enterprises involved in a breakup) to a control group (those enterprises not involved in a breakup). It goes beyond a simple comparison of means by controlling for the relevant prespinoff conditions in these firms.

Enterprise performance, $\pi$, may be measured in a number of ways. To provide a relatively broad set of tests, we have used three performance indicators: value added/labor, ${ }^{10}$ profit/labor, and turnover/total cost, where turnover/total $\operatorname{cost}=($ revenue + cost $) / \operatorname{cost}=1+($ profit + cost $) / \operatorname{cost}=$ $2+$ profit/cost constitutes an alternative measure of the profitability of the firm.

Profitability is the traditional and most widely used measure of performance. We use two alternative measures-one direct (scaled by labor) and one indirect (scaled by total cost) - to check how sensitive the findings are to these different measures of performance. At least two reasons justify also using value added per worker as a performance variable. First, value added per worker is a measure of productive efficiency of the firm when we analyze the impact of breakups on value added per worker, while controlling for variables that approximate an arbitrary production function. In this sense, our analysis may be seen as testing the impact of breakups on productive efficiency. Second, value added per worker is traditionally assumed to be one of the likely objective functions of labor-managed firms (Ward, 1958; Vanek, 1970; Prasnikar et al., 1994). Because worker-insiders are widely believed to have gained influence in enterprises during the transition (Blanchard, 1997; Burda, 1993) and microevidence indicates that they

\footnotetext{
${ }^{8}$ See Lizal et al. (1995) for details. Note, also, that data problems related to the 1993 dissolution of Czechoslovakia and the completion of the first wave of privatization have prevented us from extending our panel beyond 1992.

${ }^{9}$ Lichtenberg and Siegel (1987) have found that poorly performing firms are more likely to change ownership. However, as was pointed out by Stiglitz (p. 682 in discussion to Lichtenberg and Siegel (1987)) Lichtenberg and Siegel have a biased sample because the results are conditioned on the fact that the firm has survived in the sample: that is, it was not closed down because of inferior performance. Our sample does not suffer from this flaw because there were no shutdowns in Czechoslovakia in the period under study.

${ }^{10}$ The data sets did not contain ready measures of value added, and so we have constructed a proxy for it by adding profit and labor costs.
} 
Table 1.-The Average Size of a Spinoff and the Typical Sample Size

\begin{tabular}{|c|c|c|c|c|c|}
\hline Master Enterprises & $\begin{array}{l}\text { Average } \\
\text { Spinoff }\end{array}$ & $\begin{array}{l}\text { Standard } \\
\text { Deviation }\end{array}$ & $\begin{array}{c}\text { Number of Spinoffs of } \\
\text { Master Enterprises/Total } \\
\text { Available Sample (Typical) }\end{array}$ & $\begin{array}{l}\text { Minimum } \\
\text { Spinoff }\end{array}$ & $\begin{array}{l}\text { Maximum } \\
\text { Spinoff }\end{array}$ \\
\hline Entire sample 1990 & $31.1 \%$ & $17.0 \%$ & $118 / 432$ & $5.3 \%$ & $70.8 \%$ \\
\hline Analyzed in 1991 & $28.3 \%$ & $15.6 \%$ & $66 / 373$ & $5.3 \%$ & $68.2 \%$ \\
\hline Analyzed in 1992 & $29.5 \%$ & $16.7 \%$ & $50 / 260$ & $5.3 \%$ & $68.2 \%$ \\
\hline $\begin{array}{l}\text { Spun-off units linked } \\
\text { with master enterprises }\end{array}$ & $\begin{array}{l}\text { Average } \\
\text { Spinoff }\end{array}$ & $\begin{array}{l}\text { Standard } \\
\text { Deviation }\end{array}$ & $\begin{array}{c}\text { Number of Spun-off } \\
\text { Enterprises in the Sample }\end{array}$ & $\begin{array}{l}\text { Minimum } \\
\text { Spinoff }\end{array}$ & $\begin{array}{l}\text { Maximum } \\
\text { Spinoff }\end{array}$ \\
\hline (Subsidiaries) & $28.7 \%$ & $15.0 \%$ & 27 & $8.1 \%$ & $70.8 \%$ \\
\hline
\end{tabular}

The size of a spinoff is measured as a percentage of the labor force of the master enterprise

The number of enterprises in the 1992 regressions varies because of the unavailability of data for some variables.

The size of a spun-off subsidiary is measured as a percentage of the labor force of the former master enterprise.

tend to appropriate a significant portion of value added (Prasnikar \& Svejnar, 1998), an analysis of the impact of breakups on value added per worker is useful as it measures the impact on what is arguably an important objective of the firm.

The performance variables are based on 1991 and 1992 annual data and the effect of the split can be captured by allowing the expected future performance to be a function of two sets of arguments:

$$
\begin{aligned}
& E\left(\pi_{\text {after split }}\right) \\
& \quad=\pi(\text { spinoff characteristics } \mid \text { pre-spinoff characteristics }),
\end{aligned}
$$

where the spinoff characteristics capture the effect of the split, and the pre-spinoff characteristics are 1990 firmspecific indicators that represent the available information from which the expectations of a future performance of the enterprise might be inferred.

Because the effect on performance may vary with the size of the spinoff, we estimate the spinoff effect as a linear function of the size of the spinoff. In particular, using data on the spun-off subsidiaries and master enterprises that experienced breakups as well as those that did not, we estimate coefficients $\alpha_{0}, \alpha_{1}$, and vector $\beta$ in the following model:

$$
\pi_{i}=\beta^{\prime} X_{i}+\alpha_{0} d_{i}+\alpha_{1} d f_{i}+e_{i},
$$

where index $i$ denotes firms,

$\pi_{i}$ is a measure of enterprise performance,

$X_{i}$ are variables controlling for pre-spinoff conditions,

$d_{i}$ is a dummy variable coded 1 if the enterprise is a spun-off subsidiary or a master firm that experienced a spinoff and 0 otherwise,

$d f_{i}$ is the share that the labor force of the spun-off subsidiary represents in the total labor force of the master enterprise before the breakup, and

the values of $d_{i}$ and $d f_{i}$ are 0 for firms that did not experience spinoffs.

The average, minimum, and maximum values of $d f_{i}$ are reported in table 1 .
If the unobserved random characteristics of an enterprise did not influence the occurrence of a spinoff and the value of $d f_{i}$, ordinary least squares (OLS) would generate consistent estimates of the $\alpha$ 's and vector $\beta$. However, the process of determining $d_{i}$ and $d f_{i}$ is most likely correlated with unobserved characteristics of the enterprise, such as the ability of management and level of technical skill. As a result, it is likely that

$$
E\left(e_{i} \mid d_{i}\right) \neq 0, E\left(e_{i} \mid d f_{i}\right) \neq 0 .
$$

The error term in equation (1) is hence likely to be correlated with $d_{i}$ and $d f_{I}$, and OLS estimates are likely to be inconsistent. The solutions for this problem are well known (Maddala, 1983; Heckman \& Singer, 1985), with the simplest and most robust one being the use of instrumental variables (IVs) in which the instruments for $d_{i}$ and $d f_{i}$ are variables that are correlated with $d_{i}$ and $d f_{i}$ but not with $e_{i}$. In theory, maximum-likelihood estimation (MLE) is more efficient, but, in the presence of the dummy and share variables, MLE requires numerical integration and is sensitive to misspecification. Moreover, because the relative advantage of the MLE method is based on large sample properties and we have 400 or fewer observations, we use the more robust IV approach.

Our vector of control variables, $X_{i}$, consists of the following variables: labor (number of employees), labor squared, net capital, net capital squared, net capital per labor, net capital per labor squared, and industry dummy variables for seven industry groups (heavy industry; machinery; production of building materials; production of pulp, wood processing, and paper; glass and ceramics; food and beverages; and textile and leather). We thus use a simple but flexible additive form that represents a secondorder approximation to any production function. Because we are using $1990 X_{i} \mathrm{~s}$, we do not encounter the problem of endogeneity that would arise if we used current period (1991 and 1992) values of $X_{i}$ s. In fact, in 1990 the values of $X_{i}$ s were still determined by the central plan. Both the spun-off subsidiaries and all the master enterprises were thus assigned as exogenous control variables the 1990 values of $X_{i}$ s that correspond to the enterprise from which they evolved. 
TAble 2.-Estimated EfFects of a Breakup on Master Firms

\begin{tabular}{|c|c|c|c|c|c|}
\hline \multirow{2}{*}{$\begin{array}{c}\text { Dependent } \\
\text { Variable }\end{array}$} & \multicolumn{5}{|c|}{ IV Coefficients and Statistics } \\
\hline & $\alpha_{0}$ & $\alpha_{1}$ & $c[\%]$ & $R^{2}$ & $N$ \\
\hline \multicolumn{6}{|c|}{1991} \\
\hline Value added/labor & $\begin{array}{l}206.04 * * \\
(97.59)\end{array}$ & $\begin{array}{c}-542.10^{* * *} \\
(251.19)\end{array}$ & $\begin{array}{l}38.0 * * * \\
(8.1)\end{array}$ & 0.40 & 373 \\
\hline Profit/labor & $\begin{array}{l}375.27 * * \\
(175.91)\end{array}$ & $\begin{array}{c}-722.90 * \\
(382.10)\end{array}$ & $\begin{array}{l}51.9^{* * * *} \\
(12.4)\end{array}$ & 0.22 & 373 \\
\hline Turnover/cost & $\begin{array}{l}0.74 * * \\
(0.32)\end{array}$ & $\begin{array}{c}-1.49^{*} \\
(0.78)\end{array}$ & $\begin{array}{l}49.5^{* * * *} \\
(11.5)\end{array}$ & 0.08 & 373 \\
\hline \multicolumn{6}{|c|}{1992} \\
\hline Value added/labor & $\begin{array}{c}167.07 \\
(265.79)\end{array}$ & $\begin{array}{c}-499.67 \\
(545.20)\end{array}$ & $\begin{array}{c}33.4 \\
(27.2)\end{array}$ & 0.21 & 259 \\
\hline Profit/labor & $\begin{array}{c}165.84 \\
(263.58)\end{array}$ & $\begin{array}{c}-492.39 \\
(540.65)\end{array}$ & $\begin{array}{c}33.7 \\
(27.3)\end{array}$ & 0.20 & 262 \\
\hline Turnover/cost & $\begin{array}{r}-0.37 \\
(0.47)\end{array}$ & $\begin{array}{c}-0.68 \\
(0.96)\end{array}$ & $\begin{array}{l}-54.9 \\
(141.3)\end{array}$ & 0.13 & 367 \\
\hline
\end{tabular}

Estimated equation: $\pi_{i}=\beta^{\prime} X_{i}+\alpha_{0} d_{i}+\alpha_{1} d f_{i}+e_{i}$,

Values in parentheses are standard errors.

$c=$ critical size of the spinoff, defined as the size (percentage of the labor force of the original master enterprise) at which the effect of the spinoff on performance is 0 ; that is, $c=-\left(\alpha_{0} / \alpha_{1}\right) \cdot 100 \%$.

$N=$ number of observations.
$*=$ significantly different from 0 at a $10 \%$ level of significance.

$* *=$ significantly different from 0 at a $5 \%$ level of significance.

$* * *=$ significantly different from 0 at a $1 \%$ level of significance.

The sample contains 66 master enterprises that experienced a breakup in the 1991 regressions.

There are 66 master enterprises that experienced a break-up in the samples with 367 observations and 50 in the remaining 1992 regression samples.

In instrumenting $d_{i}$ and $d f_{i}$, the crucial source of identification is a set of six dummy variables for the individual supervisory ministries that made the final decisions about the proposed spinoffs (Federal Ministry of the Economy; Czech Ministries of Industry, Machinery, and Construction; and the Slovak Ministries of Economy and Industry). The six ministries were independent of one another, and their decisions were fairly idiosyncratic. Moreover, by 1991, the ministries were relaxing their supervisory functions and had only limited information about the current and future performance of the firms. Yet, because the ministries decided whether the split was to be approved or not and how exactly it was going to be carried out, the ministry dummy variables are correlated with - and hence are good predictors of - the variables measuring the occurrence and share of the spinoff. ${ }^{11}$ Because the ministries were separate for the Czech and Slovak republics, the ministry dummy variables also serve as dummy variables for the two republics.

\section{Empirical Results}

The Effects of Breakups on Master Enterprises: In this section, we present coefficient estimates of equation (1) based on data from master enterprises that experienced spinoffs and those that did not. The results are based on samples with 373 firm-level observations in 1991 and approximately 260 observations in 1992. Approximately $20 \%$ of these firms experienced a spinoff.

\footnotetext{
${ }^{11}$ The correlations between industry dummies used in the $X_{i}$ vector of control variables and the ministry dummies that identify the effect of the spinoff variables are fortunately quite low. Although in one industry, the correlation coefficient reaches 0.78 , but all other correlation coefficients are below 0.4 .
}

In table 2 , we present the estimated IV coefficients $\alpha_{0}$ and $\alpha_{1}$, with the upper half of the table containing the estimates for 1991 and the bottom half for 1992. As may be seen from table 2, all three estimates of $\alpha_{0}$ and $\alpha_{1}$ for 1991 are statistically significant. The performance effect declines with the size of the spinoff, being positive for small, medium-sized, and slightly above average-sized spinoffs, but becoming negative for those that are significantly above average in size. As we show in column c of table 2, the size of spinoff at which the effect turns from positive to negative (38\% for value added per worker, $52 \%$ for profit per worker, and $50 \%$ for turnover/cost) exceeds the average spinoff size of $30 \%$ reported in table $1 .{ }^{12}$ The results thus suggest that, in the short run, master enterprises that experienced small to slightly above average spinoffs gained in terms of both efficiency and profitability - a finding that is consistent with hypotheses 1 and 3 of section II. In contrast, firms that lost more than $38 \%$ of their labor force through a spinoff suffered in terms of value added per worker. Those that lost more than $50 \%$ of their labor in the spinoff also experienced a negative effect in terms of profit/labor and turnover/cost. Because we are measuring the effect immediately after the breakup, a possible explanation of the negative impact of large spinoffs $\left(\alpha_{1}<0\right)$ is that they necessitate more funda-

\footnotetext{
${ }^{12}$ The size at which the effect changes from positive to negative may be referred to as the "critical size" of the spinoff. In our case, it is measured in terms of the labor share of the master enterprise that experienced a spinoff. As may be seen from the calculated values in tables 2 through 4 , the 1991 estimates of the critical size of the spinoff range from $38 \%$ to $52 \%$ for master firms, $31 \%$ to $34 \%$ for spun-off subsidiaries, and $34 \%$ to $45 \%$ for the joint estimates. The effect of the spinoff is thus estimated to be positive within a sizable range of spinoff values, including the average spinoff size of approximately $30 \%$ (table 1 ).
} 
TABle 3.-Estimated EfFects of a BREAKup on the Subsidiaries

\begin{tabular}{|c|c|c|c|c|c|}
\hline \multirow{2}{*}{$\begin{array}{c}\text { Dependent } \\
\text { Variable }\end{array}$} & \multicolumn{5}{|c|}{ IV Coefficients and Statistics } \\
\hline & $\alpha_{0}$ & $\alpha_{1}$ & $c[\%]$ & $R^{2}$ & $N$ \\
\hline \multicolumn{6}{|c|}{1991} \\
\hline Value added/labor & $\begin{array}{c}225.57 * \\
(123.44)\end{array}$ & $\begin{array}{r}-732.54^{*} \\
(385.70)\end{array}$ & $\begin{array}{l}30.8 * * * \\
(6.2)\end{array}$ & 0.18 & 334 \\
\hline Profit/labor & $\begin{array}{l}434.72 * * \\
(210.50)\end{array}$ & $\begin{array}{c}-1375.61 * * \\
(588.16)\end{array}$ & $\begin{array}{l}31.6 * * * \\
(5.9)\end{array}$ & 0.09 & 334 \\
\hline Turnover/cost & $\begin{array}{l}1.31 * * \\
(0.53)\end{array}$ & $\begin{array}{c}-3.81^{* * *} \\
(1.48)\end{array}$ & $\begin{array}{l}34.3^{* * * *} \\
(4.5)\end{array}$ & 0.00 & 334 \\
\hline \multicolumn{6}{|c|}{1992} \\
\hline Value added/labor & $\begin{array}{c}201.17 \\
(468.67)\end{array}$ & $\begin{array}{l}-713.58 \\
(1399.9)\end{array}$ & $\begin{array}{c}28.2 \\
(19.4)\end{array}$ & 0.15 & 224 \\
\hline Profit/labor & $\begin{array}{l}1230.90^{*} \\
(646.24)\end{array}$ & $\begin{array}{c}-3717.06^{* *} * \\
(1894.59)\end{array}$ & $\begin{array}{l}33.1 * * * \\
(4.7)\end{array}$ & 0.02 & 224 \\
\hline Turnover/cost & $\begin{array}{c}0.64 \\
(0.77)\end{array}$ & $\begin{array}{c}-3.33 \\
(2.09)\end{array}$ & $\begin{array}{c}19.3 \\
(12.3)\end{array}$ & 0.00 & 324 \\
\hline
\end{tabular}

Notes are the same as for table 2 except:

there are 27 subsidiaries in the sample for the 1991 regressions.

there are 22 subsidiaries in the sample with 324 observations and 12 subsidiaries in the sample with 224 observations for the 1992 regressions.

mental restructuring than do small spinoffs, with performance suffering in the short term during the adjustment process. $^{13}$

The estimates reported in the bottom panel of table 2 refer to 1992, and, for value added and profit per worker, they are based on a smaller sample than are those for 1991, because approximately $30 \%$ of firms did not report data on labor in 1992. As is evident from table 2, although in the case of value added and profit per worker the estimated 1992 coefficients have the same signs as those for 1991, the estimated standard errors are relatively large and the estimated effects are statistically insignificant. The decline in statistical significance of the negative effect of large spinoffs $\left(\alpha_{1}<0\right)$ between 1991 and 1992 is consistent with the above-mentioned explanation that large spinoffs necessitated more fundamental (and, hence, costly) restructuring in 1991 and that this negative effect on performance might have tapered off by 1992. The question that remains, however, is why the effect becomes statistically insignificant between 1991 and 1992 for spinoffs of all sizes. We have pursued this issue by checking if the decrease in statistical significance of the estimates of $\alpha_{0}$ and $\alpha_{1}$ between 1991 and 1992 is caused by a decrease in the sample size or by other phenomena. To do so, we have reestimated the 1991 value added/labor and profit/labor regressions using only data from those firms that constitute the 1992 sample. The resulting estimates have the same signs as those in table 2 , with three of the four estimates being statistically insignificant. Thus, these findings indicate that the decrease in the sample size could be the cause of decline in statistical significance observed in table 2 between 1991 and 1992.

\footnotetext{
${ }^{13}$ We are indebted to an anonymous referee for pointing out this explanation to us. A competing explanation would be that sizable breakups created strongly competing firms that drove down product prices, nominal value added, and profits. However, as we show presently, this latter explanation is not supported by the weakening of the effect in 1992.
}

In contrast, the 1992 estimates for turnover/cost, reported in the bottom panel of table 2, are based on a very similar number of observations as the 1991 estimates reported in the upper panel of the table. For this indicator, the issue of a reduced sample size does not arise, and the insignificance of the 1992 estimates of the effect of the breakups is attributable to other phenomena, such as increased competition and dissipation of profits by management (hypothesis 4).

Effects of a Spinoff on the Subsidiary: In this subsection, we focus on the difference between the performance of spun-off subsidiaries and enterprises that did not experience spinoffs. The total sample size is approximately the same as before (334 observations for all three indicators in 1991, and 224 observations for value added and profit per worker in 1992), but there are only 27 observations on the spun-off subsidiaries in 1991 and, in the case of value added and profit per worker, only 12 in 1992.

In the upper half of table 3, we present the estimated effects for 1991. As was the case for master enterprises that experienced spinoffs, we find that the estimated effects of a spinoff on the newly independent subsidiary's value added per worker, profit per worker, and the ratio of turnover to cost are statistically significant, with $\alpha_{0}>0$ and $\alpha_{1}<0$. The 1991 estimates, hence, again yield the performance effect as a negative function of the relative size of the spinoff, with the effect being positive for small to average-sized spinoffs (consistent with hypotheses 2 and 3 ) and negative for above average-sized spinoffs (consistent with the explanation based on sizable adjustment costs).

The estimates for 1992, reported in the bottom half of table 3, show the effect to be negatively related to the size of the spinoff $\left(\alpha_{0}>0\right.$ and $\left.\alpha_{1}<0\right)$ for profit/labor and insignificant $\left(\alpha_{0}=\alpha_{1}=0\right)$ for value added/labor and turnover/cost. Thus, there is again evidence of a weakening 
TABle 4.-Joint Estimates of the EFfects of A BREAKuP

\begin{tabular}{|c|c|c|c|c|c|c|}
\hline \multirow{2}{*}{$\begin{array}{c}\text { Dependent } \\
\text { Variable }\end{array}$} & \multicolumn{6}{|c|}{ IV Coefficients and Statistics } \\
\hline & $\alpha_{0}$ & $\alpha_{1}$ & $c[\%]$ & $R^{2}$ & $N$ & $p$-value \\
\hline \multicolumn{7}{|c|}{1991} \\
\hline Value added/labor & $\begin{array}{c}126.05^{*} \\
(65.63)\end{array}$ & $\begin{array}{c}-375.67 * * \\
(181.58)\end{array}$ & $\begin{array}{l}33.6 * * * \\
(7.8)\end{array}$ & 0.46 & 400 & 0.43 \\
\hline Profit/labor & $\begin{array}{l}242.83 * * \\
(112.32)\end{array}$ & $\begin{array}{c}-503.78 * * \\
(240.84)\end{array}$ & $\begin{array}{l}42.8 * * * \\
(11.8)\end{array}$ & 0.32 & 400 & 0.27 \\
\hline Turnover/cost & $\begin{array}{l}0.53 * * \\
(0.21)\end{array}$ & $\begin{array}{c}-1.18 * * \\
(0.53)\end{array}$ & $\begin{array}{l}44.7 * * * \\
(9.1)\end{array}$ & 0.14 & 400 & 0.23 \\
\hline \multicolumn{7}{|c|}{1992} \\
\hline Value added/labor & $\begin{array}{c}-7.55 \\
(163.67)\end{array}$ & $\begin{array}{r}-373.25 \\
(423.35)\end{array}$ & $\begin{array}{l}-2.0 \\
(45.9)\end{array}$ & 0.22 & 274 & 0.91 \\
\hline Profit/labor & $\begin{array}{c}237.40 \\
(210.81)\end{array}$ & $\begin{array}{r}-696.37 \\
(479.04)\end{array}$ & $\begin{array}{l}34.1 * * \\
(15.0)\end{array}$ & 0.17 & 274 & 0.22 \\
\hline Turnover/cost & $\begin{array}{r}-0.12 \\
(0.28)\end{array}$ & $\begin{array}{c}-0.83 \\
(0.68)\end{array}$ & $\begin{array}{c}-14.5 \\
(45.1)\end{array}$ & 0.13 & 389 & 0.55 \\
\hline
\end{tabular}

Notes are the same as for table 2 except:

$p$-value $=p$-value of the $X_{(2)}^{2}$ test of the equality of the effects of a spinoff on the subsidiaries and master firms.

$p$-value $=p$-value of the $X_{(2)}^{2}$ test of the equality of the effects of a spinoff on the subsidiaries and master firms.
The sample contains 27 subsidiaries and 66 master enterprises that experienced a break-up in the 1991 regressions.

There are 22 subsidiaries and 66 master enterprises that experienced a breakup in the sample with 389 observations and 12 subsidiaries and 50 master enterprises experiencing a breakup in the other samples for the 1992 regressions.

effect of spinoffs over time, but the weakening is less uniform than in the case of the master enterprises. Taken together, the 1991 and 1992 results in table 3 are consistent with the explanation that more sizable breakups cause more substantial short-term adjustment costs and hence have a negative effect on performance in the short run. In the case of profit/labor, this negative effect seems to prevail through 1992. As before, we have reestimated the 1991 value added/ labor and profit/labor regressions using data from only those firms that are present in the 1992 sample. Unlike the mixed results that we found for master enterprises that experienced breakups, the present reestimation generates statistically significant coefficients that have the same signs and similar values as those in the upper part of table 3 . In the case of the spun-off subsidiaries, the weakening of statistical significance over time thus appears to be brought about by phenomena such as increased competition and the dissipation of profits by management (hypothesis 4), rather than by reduced sample size.

Joint Estimates: In view of the similar estimates obtained for the master firms that experienced spinoffs and for the spun-off units, we have also performed joint estimation and tested the hypothesis that spinoffs have equal effects on these two sets of firms. As may be seen from table 4, the joint estimates are similar to those found in the separate regressions for master firms that experienced spinoffs and for spun-off subsidiaries. Moreover, as the $p$-values in the last columns of the tables indicate, on the basis of $X_{(2)}^{2}$ tests, one cannot reject the hypothesis that for each performance indicator the effect of the breakup is identical for the spun-off subsidiaries and the remaining master firms. The separate as well as joint 1991 estimates for small, medium, and slightly above average spinoffs hence provide support for hypothesis 3 (SOEs suffer from inefficiencies such as diseconomies of scale, and breakups result in a superior performance of both the spun-off units and the remaining master enterprises) as opposed to hypotheses 1 and 2 (breakups occur because either master enterprises or subsidiaries are more efficient).

We have also generated joint 1991 estimates for value added/labor and profit/labor using only data from firms that are present in the 1992 sample. These new estimates and the estimates for turnover/cost in tables 4 show that five of the six relevant coefficients are statistically significant. These results hence indicate that the decline in the statistical significance of the joint estimates between 1991 and 1992 is brought about primarily by phenomena such as increased competition and possible dissipation of profits by managers (hypothesis 4$).^{14}$

\section{Concluding Observations}

In terms of altering the number and size of firms, as well as bringing in new top management, one of the most important forms of enterprise restructuring observed in a number of transition economies was the breakup of the large state-owned enterprises (SOEs). Our econometric estimates suggest that the major wave of SOE breakups that took place in Czechoslovakia in the early 1990s had a significant immediate effect on the efficiency and profitability of industrial firms. The effect was positive for small, medium, and slightly above average-sized spinoffs but negative for

\footnotetext{
${ }^{14}$ Finally, we have used the 1991 and 1992 data to carry out estimation on first differences. The estimated coefficients in this fixed-effects specification are by and large statistically insignificant. We hoped to generate information from changes of performance over time, but our finding of a lack of statistical significance is not altogether surprising, given that we found the 1992 level estimates to have relatively large standard errors and to be themselves statistically insignificant at conventional statistical test levels.
} 
the very large ones. We also cannot reject the hypothesis that the estimated effect of spinoffs on performance was identical for the spun-off subsidiaries and the master enterprises that experienced the spinoffs. Taken together, the positive short-term effects on performance of both the master firms and the spun-off units are consistent with our hypothesis 3, namely that the large SOEs suffered from inefficiencies that were rapidly alleviated by the breakups into smaller units. The finding that the short-term performance effect was negative for very large spinoffs is in turn consistent with the explanation that sizable breakups caused large adjustment costs and thus had a negative short-term effect on performance.

We also find that most 1992 estimates are similar to those for 1991 but that many yield statistically insignificant effects, including the negative one for the sizable breakups. To explain this finding, we first control for the fact that, for two of the three performance indicators (value added/labor and profit/labor), we have significantly fewer observations for 1992 than 1991. By reproducing 1991 estimates with data from firms that are present in only the 1992 sample, we are able to control for the reduction in sample size and establish that the weakening of the statistical significance is, in most cases, not attributable to the decrease in the sample size. We conclude that the insignificance is likely generated by the increased competition brought about by the breakups of the large firms into competing units and the 1992 elimination of the $20 \%$ import surcharge (the main trade protection measure), as well as by the growing phenomenon of profit dissipation by management as central controls were gradually eroded. The latter interpretation reflects hypothesis 4 and is consistent with recent reports of the siphoning off of profits and asset stripping ("tunneling") by managers in the Czech Republic, Slovakia, Russia and other transition economies with weak ownership structures.

\section{REFERENCES}

Aghion, Philippe, Olivier Blanchard, and Robin Burgess, "The Behaviour of State Firms in Eastern Europe, Pre-privatisation," European Economic Review 38(6) (1994), 1327-1349.

Alchian, Armen A., and Harold Demsetz, "Production, Information Costs, and Economic Organization," American Economic Review 65(2) (1972), 777-795.

Blanchard, Olivier, The Economics of Post-Communist Transition (Oxford: Clarendon Press, 1997).

Burda, Michael, "Unemployment, Labour Markets and Structural Change in Eastern Europe," Economic Policy 8(16) (1993), 101-128.

Chandler, Alfred Jr., Scale and Scope (Cambridge: Belknap Press, 1990).

Coase, Ronald H., "The Nature of the Firm," Economica 4 (1937), reprinted in George J. Stigler and Kenneth E. Boulding (Eds.), Readings in Price Theory (Homewood, Ill.: Irwin (1952).

Drabek, Zdenek, and Alasdair Smith, "Trade Performance and Trade Policy in Central and Eastern Europe," CEPR discussion paper no. 1182 (May 1995).

Dyba, Karel, and Jan Svejnar, "A Comparative View of Economic Developments in the Czech Republic," in Jan Svejnar (Ed.), The Czech
Republic and Economic Transition in Eastern Europe (San Diego: Academic Press, 1995).

Ellerman, David, "Voucher Privatization with Investment Funds," The William Davidson Institute working paper no. 167 (University of Michigan Business School, 1998).

Grossman, Sanford J., and Oliver D. Hart, "The Costs and Benefits of Ownership: A Theory of Vertical and Lateral Integration," Journal of Political Economy 94(4) (1986), 691-719.

Hart, Oliver D., and John Moore, "Property Rights and the Nature of the Firm," Journal of Political Economy 98(6) (1990), 1119-1158.

Heckman, James, and Burton Singer, Longitudinal Analysis of Labor Market Data (Cambridge: Cambridge University Press, 1985).

Jorgenson, Dale, "Comments on Lichtenberg, Frank R., and Donald Siegel, 'Productivity and Changes in Ownership of Manufacturing Plants,' " Brooking Papers on Economic Activity, special issue, 3 (1987) 674-678.

Kaplan, Steven N., and Michael S. Weisbach, "The Success of Acquisitions: Evidence from Divestitures," The Journal of Finance 47(1) (1992), 107-138.

Klein, Benjamin, Robert G. Crawford, and Armen A. Alchian, "Vertical Integration, Appropriable Rents, and the Competitive Contracting Process," Journal of Law and Economics 21(2) (1978), 297-326.

Kotrba, Josef, "Privatization Process in the Czech Republic: Players and Winners," in Jan Svejnar (Ed.), The Czech Republic and Economic Transition in Eastern Europe (San Diego: Academic Press, 1995).

Lichtenberg, Frank R., and Donald Siegel, "Productivity and Changes in Ownership of Manufacturing Plants," Brooking Papers on Economic Activity, special issue, 3 (1987), 643-683.

Lizal, Lubomir, Miroslav Singer, and Jan Svejnar, "Manager Interests, Breakups and Performance of State Enterprises in Transition," in Jan Svejnar (Ed.), The Czech Republic and Economic Transition in Eastern Europe (San Diego: Academic Press, 1995).

Maddala, Gangadharrao S., Limited Dependent and Qualitative Variables in Econometrics (New York: Cambridge University Press, 1983).

Prasnikar, Janez, and Jan Svejnar, "Investment, Wages and Ownership during the Transition to a Market Economy: Evidence from Slovenian Firms," The William Davidson Institute working paper no. 184, (University of Michigan Business School, 1998).

Prasnikar, Janez, Jan Svejnar, Dubravko Mihaljek, and Vesna Prasnikar, "Behavior of Participatory Firms in Yugoslavia: Lessons for Transforming Economies," this REVIEW 76(4) (1994), 728-740.

Radner, Roy, and Timothy van Zandt, "Information Processing in Firms and Returns to Scale," Annales D'Economie Et De Statistique 25-26 (1992), 265-298.

Ravenscraft, David J., and Frederic M. Scherer, "Life after Takeover," The Journal of Industrial Economics 36(2) (1987), 147-156.

Shleifer, Andrei, and Robert W. Vishny, "Politicians and Firms," Quarterly Journal of Economics 109(4) (1994), 945-1026.

Stiglitz, Joseph, "Whither Reform? Ten Years of the Transition," Paper presented at the 1999 Annual Bank Conference on Development Economics, World Bank, Washington, D.C. (1999).

Vanek, Jaroslav, The General Theory of Labor-Manager Market Economies (Ithaca, NY: Cornell University Press, 1970).

Ward, Benjamin, "The Firm in Illyria: Market Syndicalism," American Economic Review 48(4) (1958), 566-589.

Weiss, Andrew, and Greorgiy Nikitin, "Performance of Czech Companies by Ownership Structure," The William Davidson Institute working paper no. 186 (University of Michigan Business School, 1998).

Williamson, Oliver E., Markets and Hierarchies: Analysis and Antitrust Implications (New York: Free Press, 1975).

Williamson, Oliver E., The Economic Institutions of Capitalism: Firms, Markets, Relational Contracting (New York: Free Press, 1985).

World Bank, World Development Report 1996 (Washington, D.C.: World Bank, 1996).

Zemplinerova, Alena, and Josef Stibal, "Czech Manufacturing," in Jan Svejnar (Ed.), The Czech Republic and Economic Transition in Eastern Europe (San Diego: Academic Press, 1995). 